\title{
The Knowledge, Behaviour, Attitudes and Perception of Young Nigerian Adults towards HIV/AIDS and its Prevention: A Systematic Review
}

\author{
Udo Orukwowu*, Boma Iweriso George and Janet Ene-Peter \\ Department of Nursing Sciences, Faculty of Basic Medical Sciences, College of Medical Sciences, Rivers State University, \\ Nigeria. \\ *Corresponding author email: udocd27@gmail.com; Phone: +2349060039098
}

\begin{abstract}
This piece of work is a systematic review that critically appraises past research studies, not later than five years that is directed towards investigating the knowledge, awareness, behaviour, attitudes and perception of young people in Nigeria towards HIV/AIDS and its prevention. Young people's knowledge, awareness and perceptions have been identified in different levels and categories. Young people's preventive awareness level and risk perceptions have also been revealed. Conclusively, the findings from the different studies selected for the systematic review have shown varying degrees of HIV knowledge among young people. This is to address the perceptions of young Nigerian adults towards HIV/AIDS. Significantly, the systematic review undertaken confirms the original theme of the study identifying and exploring the knowledge, attitudes, behaviours and perceptions of young adults to address the aim of the study. The results have, therefore, indicated that those in the colleges and universities were more knowledgeable than those that were not. Understanding of the virus helped to influence young people in their attitude towards infected people. Furthermore, understanding of HIV/AIDS and its prevention also differed among young adults; those in the university had better understanding compared to those in the colleges and dropouts.
\end{abstract}

Keywords: HIV/AIDS awareness, HIV prevention, HIV/AIDS in young adults, HIV/AIDS in Nigeria
Article History

Received: 15 Jan 2022

Accepted: 02 Feb 2022

Published: 10 Feb 2022

Scan $Q R$ code to view ${ }^{\circ}$

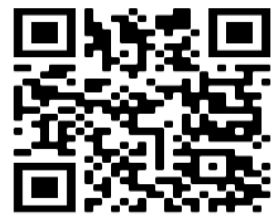

License: CC BY 4.0`

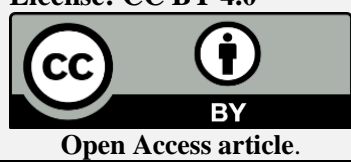

How to cite this paper: Orukwowu, U., George, B.I. and Ene-Peter, J. (2022). The Knowledge, Behaviour, Attitudes and Perception of Young Nigerian Adults towards HIV/AIDS and its Prevention: A Systematic Review. IPS Journal of Basic and Clinical Medicine, 1(1), 1-12. https://doi.org/10.54117/ijbcm.v1i1.1.

\section{Introduction}

Human Immunodeficiency Virus (HIV) and Acquired Immunodeficiency Syndrome (AIDS) has had a devastating impact to the sufferers and the society in general (Stolley and Glass, 2009; Gallant, 2012). HIV/AIDS has been regarded as one of the major public health problems and a global epidemic that occurs both in the developing and developed world (Karim and Karim, 2010). The virus was detected in the 1980's and has already killed millions of affected people, bringing a great burden to the economy of various countries (Horton, 2008). Consequently, the HIV virus has been known to have great negative impacts on the socioeconomic status of families, communities, societies of the affected, especially in the developing countries according to Stolley and Glass, 2009. Indeed, Upreti (2009:1) indicated that HIV/AIDS has been recorded the world's most destructive epidemic. HIV/AIDS has equally been attributed to be a main cause of death especially in the developing world (Gallant, 2012).

HIV/AIDS has become a major public health challenge and a tenacious risk to young adults resulting in the increased incidence and prevalence of the virus (Horton, 2008). Christianson et al. (2009) highlighted about young men and women, where three out of five of them have insufficient knowledge regarding HIV globally. According to Jones and Mitchell (2014:1) HIV has been regarded as an "increasing epidemic among young people". As a result, the vulnerability of young adults has been alarming. However, HIV has been known to affect people of different ages, both old and young, men and women in the developing and developed world (Horton, 2008). Nevertheless, increased prevalence and incidence have been recorded among young people (Karim and Karim, 2010; Jones and Mitchell, 2014), which was a reason for this study.

Young adults have been noticed to be the centre of attraction as a result of certain risk factors (Horton, 2008). Jones and Mitchell (2014) emphasized that young people have been noticed to be the area of target (Stolley and Glass, 2009) as they are predisposed to HIV due to being sexually active, trying to explore different aspects of life without considering the consequences. According to Gallant (2012), the attitudes of young people are complex as they are affected and vulnerable to HIV due to early initiation of sex, multiple sexual partners, bisexual orientation, biological factors, involvement in drugs and sharing needles. According to the research carried out by Jones and Mitchell (2014), the lack or reduced knowledge of young adults on HIV has led them to increase participation in premarital sexual activities. Hence, there have been recorded varying degrees in the increase of incidence and prevalence of HIV in different countries and regions of the world as seen in the figures $1 \& 2$.

In 2011, the World Health Organisation (WHO) recorded that about 34 million people were living with HIV globally (WHO, 2011). In 2012, the prevalence of HIV and AIDS was alarming, giving rise to over 35.3 million of adults and 
children living with HIV, 2.3 million adults and children newly infected, (WHO/UNAID, 2012). Significantly, in a day, there was over 6,300 of new infections globally, however, low and middle-income countries had about $95 \%$ as estimated, about $47 \%$ were women and young people of between 15 24 were about 39\% (WHO/UNAID, 2012). In 2013, according to World Health Organisation (WHO), about 70 million people were infected with HIV globally (WHO, 2013).

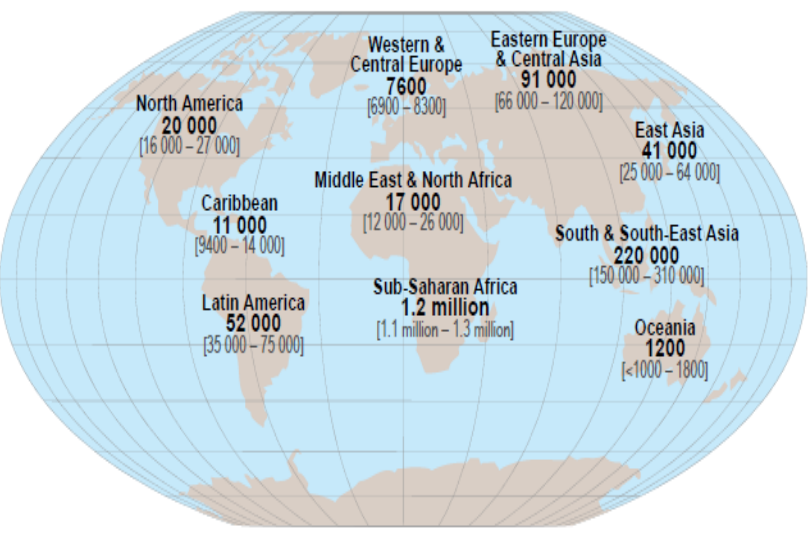

Total: 1.6 million [1.4 million - 1.9 million]

Figure 1: Estimated adult and child death from AIDS in 2012 by WHO

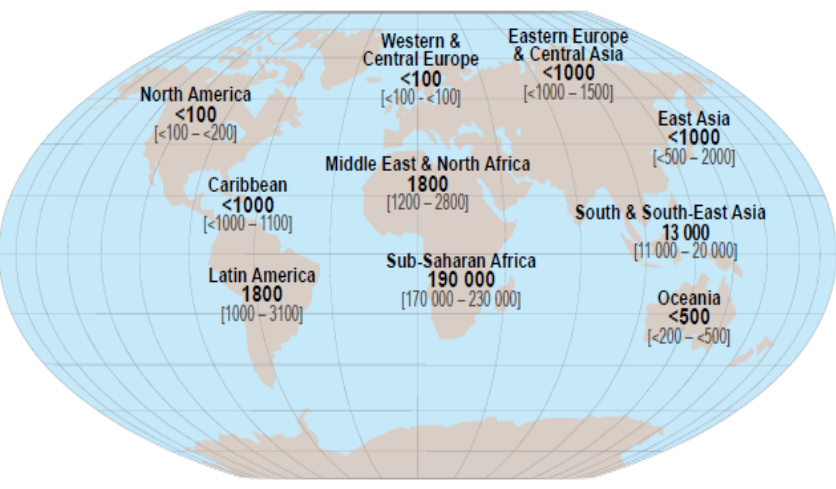

Total: $210000[190000-250000]$

Figure 2: Estimated deaths in children ( $<15$ years) from AIDS in 2012 by WHO

Regionally, In 2012 WHO recorded that Eastern Europe and Central Asia had 1.3 million, Western and Central Europe had 860000 people were living with HIV (WHO, 2012). However, Sub-Sahara Africa had the highest rate of prevalence of 25.0 million, with about 1.6 million newly infected with HIV (WHO/UNAIDS, 2013). Nationally, in 2012, it was estimated in the UK that 98,400 people were living with HIV (UK Statistics, 2013). However, 22\% were not aware of their condition (UK Statistics, 2013). In 2013, the rate of HIV infection reduced to 81,512 , however, the number has doubled the prevalence number that was recorded for 2004 which was 41,157 , due to steady increase. The HIV infection was more in men compared to women, with $67 \%$ and $33 \%$ respectively of those that accessed specialist care in 2012 (UK Statistics, 2013). However, in 2013 the estimated number of men that accessed care were 55,200 and women were 26,312, and men were still more infected than women (UK Statistics, 2013).

In Africa, HIV has continued to increase in its incidence leading to related complications due to reduced immune system, leading to an early death which could be possibly be related to ignorance or mismanagement (Adedimeji et al., 2007). However, HIV/AIDS has also been attributed to one of the major cause death in Africa, especially in Sub-Sahara Africa which has been known to have a greater burden of infection in the world (Juma and Klot, 2011). According to Ojikutu et al. (2010), Sub-Sahara Africa is known as the most hit region with two third of the overall population living with the virus. The incidence of HIV infection in Africa occurs more in young people, mostly those below 20 years according to Mass and Otte (2009). Additionally, in SubSahara Africa, a slight understanding of HIV was established, at the same time, individuals were all reluctant to adopt measures to prevent transmission during sexual intercourse (Mass and Otte, 2009). High risk behaviour in sexual activities was found generally among young people (Bernardi, 2002). It was more appalling that these youths engages in sexual behaviour, standing a high risk of getting infected (Adedimeji et al., 2007; Juma and Klot, 2011). Mos of these youths have had some form of awareness concerning HIV transmission and prevention but still stand as high risk individualas (Juma and Klot, 2011).

Hence, the incidence and prevalence of HIV has had a steady figure or increase in its occurrence among young people (Nelson and Williams, 2014). On the other hand, incidence increases regardless of the efforts made to reduce the spread of the infection. However, the governments of most African countries have put strategies in place to meet the need of the population regarding prevention, early diagnosis and treatment (Mwiturubani et al., 2009). Additionally, Juma and Klot (2011) established increased sexual violence in Africa, taking for example a study carried in Southern Africa where 1 in 4 men accepted to have raped one or more people, which increased the vulnerability of the females according to Nelson and Williams (2014).

In Nigeria, despite the different mediums of knowledge spread, the increase in the incidence of HIV is not reducing, just like some other African countries (Adedimeji, 2005). Consequently, Bernardi (2002) established lack of understanding to a major reason for the sustained increase in occurrence Evidently, Adedimeji et al. (2007) emphasized that those in the urban areas engage more in sexual practices that are risky. This is not just inadequate knowledge regarding safe sex but also showed sexual promiscuity among young people. Mass. and Otte (2009) added how active young people could be, adding to the inability to recognise the consequences of their actions, thereby facilitating the spread of the infection. This has made it a major concern in the future and implications of HIV/AIDS in the society due to lack of understand among young people (Nelson and Williams, 2014). Therefore, the aim of this study is to investigate the knowledge, attitude and perceptions of young Nigerian adults towards HIV/AIDS and its prevention.

Additionally, mortality rate of death occurring as a result of HIV and AIDS have been of varying degree (McManus and Dhar, 2008). Significantly, since 1980 when the epidemic began, over 35 million people have been recorded dead due to AIDS and related complications (UK Statistics, 2013; WHO, 2013). In 2012, it was estimated that over 1.6 million people have died due to AIDS, 1.2 million was recorded for Sub-Sahara Africa, 17,000 for Middle Eas and North Africa, 91,000 for Eastern Europe and Central Asia, 76,000 for Western and central Europe, Caribbean had 11,000, 52,000 was estimated for Latin America, 20,000 for North America, 41,000 for East Asia, South and South-East Asia was allocated 220,000 and Oceania had 1200 which was the least (WHO/UNAIDS, 2012). However, number of death declined to 1.6 in 2012 due to improved antiretroviral therapy and access to care compare to 2011 which was estimated to be 1.7 million people who died of AIDS (IDF 2013)

\section{Methodology}

\subsection{Search Strategy}

The approach of search undertaken for the systematic reviews of articles on the perceptions of young adults towards HIV and its prevention was comprehensive. This study aims to use the relevant and applicable studies identified to explore the awareness and risk of young adults including qualitative and quantitative studies. Hence, search strategies were combined to find evidence which includes hand search of journals selected, relevant websites search, electronic sources search and checking references of studies included. However, searches made were comprehensive and carried out according to the methods adopted for the development of public health guidance (NICE, 2009)

Thus, there was a logical was applied to select systematic review papers as well as the journals used for literature review to enable a critical review of literature. As a result, searches were made from Medline, PubMed, CINHAL, Science Direct and Google Scholar. Database were also searched, including; British Medical, British Medical Journal, Cochrane database, Library Catalogue, Department of Health, National Institute for Health and Clinica Excellence, World Health Organisation, Nursing and Midwifery Council. Bibliographies were also hand searched. Consequently, for a more sophisticated search, the PIO framework was applied.

\subsection{The PIO Framework}

This is to critically provide evidence of undertaken systematic and comprehensive search to appropriately find evidence for the research study. In this stage, the plan of the search strategy is paramount to adequately and 
effectively carry out the search systematically. However, in the process of the search, the included and excluded criteria will be highly considered and incorporated in the search strategy, for instance; the date range and the subject. Furthermore, the strategy to be employed for the evidenced-based comprehensive search will be the Population, Issue and Outcome (PIO) element to enhance appropriate search. Additionally, the application of the PIO element will ensure a better search strategy for a systematic approach for this study. Hence, the search question is stated below and the keywords will follow using the PIO elements.

\section{Search Question:}

"What are the knowledge, behaviours, attitudes and perceptions of young people in Nigeria towards HIV/AIDS prevention"?

Therefore, the PIO operation were presented thus;

\begin{tabular}{|c|c|c|}
\hline Population & Issue & Outcome \\
\hline $\begin{array}{ll}\text { Young Nigerian } \\
\text { Adults }\end{array}$ & $\begin{array}{l}\text { Knowledge, behaviour, } \\
\text { attitudes and perception }\end{array}$ & $\begin{array}{l}\text { HIV/AIDS } \\
\text { prevention }\end{array}$ \\
\hline
\end{tabular}

\section{Key Terms:}

\begin{tabular}{|l|l|l|}
\hline Population & Issue & Outcome \\
\hline $\begin{array}{l}\text { Nigerian young } \\
\text { people }\end{array}$ & Knowledge of HIV & HIV/AIDS \\
& HIV risk behaviour & prevention \\
& Attitudes towards HIV & \\
& $\begin{array}{l}\text { Perceptions towards } \\
\text { HIV }\end{array}$ & \\
\hline
\end{tabular}

To further perform a sophisticated search, a Boolean logic operation was applied to MEDLINE online database. These Boolean logic operations are AND, OR and NOT to enhance a logical strategy in the comprehensive search The operation was mainly for topics in health. Therefore, databases that were not related to health were excluded during the search. The sophisticated search however was made in MEDLINE online database.

\begin{tabular}{|l|l|l|}
\hline Population & Issue & Outcome \\
\hline $\begin{array}{l}\text { Nigerian young } \\
\text { people }\end{array}$ Nigerian young adults & Knowledge of HIV & HIV/AIDS \\
& OR & prevention \\
& $\begin{array}{l}\text { OR risk behaviour } \\
\text { Attitudes towards HIV } \\
\text { OR } \\
\text { Perceptions towards HIV }\end{array}$ & \\
& \\
\hline
\end{tabular}

Significantly, the below table shows the detailed systematic search evidence undertaken as a basis of searching appropriate evidence. Consequently, the search strategy is negotiated from the website of the university through to the Logical Search with Boolean Operators. Search guide is given below:

\begin{tabular}{|l|}
\hline Library and Information Services \\
\hline LibGuide \\
\hline Public Health \\
\hline Finding Journal Articles \\
\hline MEDLINE \\
\hline Logical Search with Boolean Operators \\
\hline
\end{tabular}

The following searches were carried out with the use of the AND and OR operators as below; S1 to S9 logical search:

\section{S1 logical search}

\begin{tabular}{|l|l|l|}
\hline Issue & Outcome & Population \\
\hline Knowledge & AND HIV/AIDS prevention & AND Nigerian young adults \\
\hline
\end{tabular}

\section{S2 logical search}

S2 logical search
\begin{tabular}{|l|l|l|}
\hline Issue & Outcome & Population \\
\hline Knowledge & AND HIV/AIDS prevention AND young adults \\
\hline
\end{tabular}

\section{S3 logical search}

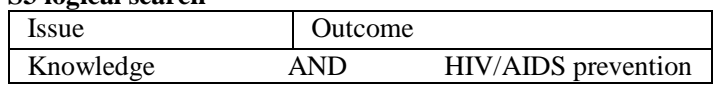

S4 logical search
\begin{tabular}{|l|l|ll|}
\hline Issue & Outcome & Population & \\
\hline $\begin{array}{l}\text { Risk behaviour } \\
\text { adults }\end{array}$ & AND & HIV/AIDS prevention & AND young \\
\hline
\end{tabular}

S5 logical search
\begin{tabular}{|l|l|}
\hline Issue & Outcome \\
\hline Risk behaviour & AND HIV/AIDS prevention \\
\hline
\end{tabular}

S6 logical search

\begin{tabular}{|l|l|l|}
\hline Issue & Outcome & Population \\
\hline Attitudes & AND HIV/AIDS prevention $\quad$ AND young adults \\
\hline
\end{tabular}

\section{S7 logical search}

\begin{tabular}{|l|l|}
\hline Issue & Outcome \\
\hline Attitudes & AND $\quad$ HIV/AIDS prevention \\
\hline
\end{tabular}

S8 logical search
\begin{tabular}{|l|l|l|}
\hline Issue & Outcome & Population \\
\hline Perceptions & AND HIV/AIDS prevention AND young adults \\
\hline
\end{tabular}

S9 logical search
\begin{tabular}{|l|ll|}
\hline Issue & outcome \\
\hline Perceptions & AND & HIV/AIDS prevention \\
\hline
\end{tabular}

The first (S1) logical search using AND operator gave zero. Therefore, another search was done. The population for the first search was "Nigerian young adults". However, it was modified to just "young adults" in the second (S2) search. This gave 25 results; it was hard to find papers that were for just Nigerian young adults. Therefore, more other searches were made to find papers that talked about Nigerian young adults. Subsequently, the third (S3) search gave a lot of results which was 743, the result of the fourth (S4) was just one (1), 47 results were found in the fifth (S5) search, the sixth (6) result was 25 just like the S2, the seventh result was 604 followed by the eighth (S8) which was just 3 and the ninth (S9) which was the last gave 95 results. However, the selected papers were according to suitability to the topic and aim of the study, satisfying the identified criteria.

Essentially, using AND and OR operations in the logical search has therefore enhanced a strategy of a logically systematic search to find evidence that is appropriate and fit to be applied in the study.

\subsection{Inclusion and Exclusion Criteria}

\subsubsection{Type of participants}

This research study is basically focused on young adults as a result of many literatures emphasizing on young adults being a major factor to the increased prevalence of HIV/AIDS infection (Christianson et al., 2008; Horton, 2008; Stolley and Glass, 2009; Gallant, 2012) Therefore, young adults are termed to be of high risk due to their activeness in sexual activities (Jones and Mitchell, 2014). The study will examine and explore the articles with high risk population indicating their knowledge, awareness and their perceptions to HIV/AIDS and its prevention. The study excluded participants that were not from Nigeria and those from other African countries other than Nigeria. The study only considered young adults

\subsubsection{Type of studies}

The information sampling retrieval technique of the selected studies included and was open to both qualitative and quantitative types of research studies. According to Holloway and Wheeler (2013), retrieving studies of from both qualitative and quantitative methods is to ensure a robust data-gathering technique for a systematic review. However, qualitative studies revealed the views, beliefs as well as perceptions of the young people (Silverman, 2010; Rapport, 2013). Conversely, the quantitative study approach looked at the extent of something occurring, measuring to know the degree of specific behaviour or a phenomenon among the group of people under study (Mooi and Garstedt, 2011). Furthermore, quantitative methods looked at cases and predictive risk factors that enhanced a better data extraction (Tracy, 2013). Importantly, the articles accepted for the systematic review were only those that were not more than five years. Although, the studies included for the review were more recent studies to ensure evidence-based practice. Hence, studies that are not current were excluded. 


\subsubsection{Type of outcomes}

There was a range of essential outcomes which includes perceptions, views, and knowledge awareness of young adults in Nigeria towards HIV and how it is being prevented. In the outcomes, knowledge and awareness of HIV involving different levels and extents of HIV awareness among the same range of age group in relation to how their environment has influenced their behaviour. Different level of knowledge on the modes of HIV transmission entails the level of understanding of the participants on what they know. The level of awareness and understanding on measures to prevent HIV and the attitude of young people towards preventing the HIisconceptions and risk perception of young people regarding HIV, its existence, mode of transmission and prevention, and factors influencing sexual behaviours among young people in Nigeria.

\subsubsection{Study selection}

The researcher independently reviewed and screened the titles of differen journals found; the researcher retrieved the abstracts of the studies found, from the database based on the exclusive and inclusive criteria as has earlier been described. Potentially, all articles relevant to the study were also retrieved to ascertain whether the inclusive criteria of the study have been met.

Initially, at the stage where the title and abstract were reviewed screened, al the studies conducted in Africa, with different age groups, relating to perceptions of individuals on HIV were reviewed and screened according to the inclusive criteria. However, all related topic were considered Consequently, abstract were critically reviewed to able to select relevant papers that addresses the aim of the research study. Importantly, looking at the research topic critically, the age group to be considered was a major criterion, as this only involved age group to be considered was a major criterion, as this only involved young people and their perceptions towards HIV and it prevention. Furthermore, the study was only young people and their perceptions towards HIV and its prevention. Furthermore, the study was only directed to address young people in Nigeria. Hence, all articles that talked about young people in other African countries were excluded. Therefore, all the papers that were chosen addressed young people in Nigeria and their perception towards HIV and its prevention.

\subsubsection{Ethical issues}

Generally, the principles of ethics are critical and required to be applied to protect the interest of the research participants (Love, 2012). This study did not require an ethical approval as it is a systematic review. However, the researcher ensured that the included studies adequately addressed ethical consideration and its approval to maintain ethical principles throughout the studies as required.

Considering that the included studies maintain the principles of ethics as applied, then this study has equally kept to ethical principles as the same anonymity and confidentiality was maintained from the data results and analysis. Nevertheless, the researcher did not have access to the original data collection scripts. Hence, there was no identification of participants all through the study. There is no need for destruction of data collected from the studies.

\subsubsection{Data extraction and quality assessment}

Relevant findings from the results of the studies identified were extracted; the extraction was verbatim from the identified studies. The extracted findings were extracted and placed in an appropriate form including the methodologica information to enhance quality and applicability of the results of the study. The sub themes and the key themes were coded accordingly in terms of the content and meaning of the sub and key themes. The researcher carried out the coding, the consistency of the emerged sub and key themes referencing the random subset of the identified studies for inclusion. The individual studies were assessed for quality.

\subsubsection{Data analysis method}

The analysis of the studies included in this report identifies and reviews the views, attitudes, experiences and perception of young people in Nigeria towards HIV and its prevention. The method adopted for analysis in this research study is based on thematic analysis approach. However, the result will included both qualitative and quantitative studies but their synthesis will be based on qualitative interpretation, reporting the results with supports from the literature. Basically, the interpretation will follow both deductive and inductive approaches in its presentation

Inductive approach is generally applied in qualitative research methods as it is data driven, reaching conclusions and building theories from identified patterns in the data set (Saunders et al., 2009; Collins, 2010). However, theories will be applied to aid argument in the analysis and discussion through the application of the deductive approach. In essence, the deductive approach is theory driven, applying theories before and during the data analysis (Hair $e t$ al., 2011).

Basically, the data analysis followed thematic analysis approach in analysing the collected data from the systematic review papers. Hence, qualitative approach was using throughout the data collection and the analysis of the collected data. According to Braun and Clarke (2013) thematic analysis focuses on how explicit and implicit ideas could be identified and described through familiarising yourself with your data, transcribing of verbal data generating initial codes, searching for themes, reviewing themes, defining and naming themes and producing the report.

\section{Results}

\subsection{Identification and Presentation of Included Papers}

The selection of included papers was based on meeting the criteria based on answering the research question as stated above. However, a total 12 papers were selected for the review after a number of results from the different databases and search engines. However, a hand search was also applied to be able to choose from a variety of studies the ones that can answer the research questions. Below are the research author and titles of the papers selected.

\subsection{Presentation of Included Studies}

The studies selected is summarized in the Table 1 in terms of the author, country where it was written, the age and the number of the participants involved and the methods of data collected used.

\section{Discussion}

This section discussed in different headings/themes considering twelve papers found to address the research question. Theories and literature will be used to support the discussion of the results and themes.

\subsection{Knowledge and Awareness of HIV/AIDS}

The chosen studies for the systematic review identified different levels of knowledge and awareness of HIV/AIDS among young people in Nigeria. In the study of Bamise et al. (2011), it was revealed that young people showed very low knowledge level about HIV/AIDS. In their study, knowledge of HIV entails causes and the transmission of the HIV virus. Consequently, the responses from the young people were disappointing, specifying that HIV virus can be transmitted through sharing the same bathrooms with an infected person, holding hands with an infected person. The most disappointing was some that stated that HIV can be transmitted through touching and hugging someone carrying the virus, sleeping in the same room with the victim, sharing meal with HIV infected person. They also stated HIV can be transferred through kissing and mosquito bites. The results have shown lack of knowledge among young people which needs attention as Okonofua (2013) has argued that it can lead to risk-taking behaviours.

Similarly, Ebeniro 2010 had equally made the same discovery, establishing little or no knowledge and awareness of HIV among young people in Nigeria. In the study, young people indicated that HIV can also be transmitted through kissing, handshakes and hugging. The results from these studies have equally shown a lack of knowledge among young people over time. On the same vein, other studies such as from Arogundade and Faloore (2012), Jimo (2012), Ebong and Ebong(2013), Eno et al. (2013) have equally shown very little or no knowledge of HIV infection, the causes and mode of transmission as well as preventive measures. Lack of knowledge has been identified among university dropouts despite the exposure to the university environment, the university dropout was only able to state that HIV "is a disease in the body where positive and negative blood comes together and can be transmitted through "Kissing and sharing of a cup". Similarly, another university dropout could only identify "going to a party", "truancy in school", "using the same underwear, cup and eyeglasses as a mode of transmission indicating lack of knowledge.

Globally, the main strategy for HIV is to reduce the spreading rate of the virus among the population to lessen the impact of the epidemic to the productive population (Okonofua, 2013). Hence, governments and non-governmental organisations such as World Health Organisation are providing the necessary facilities and services required to minimize the spread of the virus (WHO, 2012). However, in Nigeria, the efforts to reduce the spread of the virus seem to be in vain as some university students lack knowledge and awareness about the HIV virus, how it can be transmitted or prevented (Eno et al al., 2013). Consequently, Okonofua (2013) has established a closed relationship between awareness and HIV spread among young people in Nigeria as has been shown in this study. 
Table 1: Presentation of included studies

\begin{tabular}{|c|c|c|c|}
\hline References & Country & Participants & Date Collection Method \\
\hline Mberu (2010). & Nigeria & $\begin{array}{l}1,308 \text { premarital } \\
\text { sexually initiated youth aged } 15-24\end{array}$ & $\begin{array}{l}\text { This study uses data from the } 1999 \text { and } 2003 \text { Nigeria Demographic } \\
\text { and Health Surveys (NDHS), }\end{array}$ \\
\hline $\begin{array}{l}\text { Eno et al. } \\
\text { (2013) }\end{array}$ & Nigeria & $\begin{array}{l}\text { Young people from } 4 \text { Local Government Areas. } \\
\text { Participants included students in tertiary institutions, } \\
\text { senior secondary schools, people living with HIV, } \\
\text { and female out of school youths }\end{array}$ & Group Discussion methodology \\
\hline $\begin{array}{l}\text { Oladepo and } \\
\text { Fayemi (2011) }\end{array}$ & Nigeria & $\begin{array}{l}\text { A total of } 420 \text { respondents ( } 52 \% \text { males and } 48 \% \\
\text { females) }\end{array}$ & $\begin{array}{l}\text { The study was a descriptive cross-sectional survey of students in } \\
\text { Ibadan South-West Local Government Area. Respondents were } \\
\text { selected through a multistage sampling technique, completed a } \\
\text { semi-structured questionnaire. This was supplemented with eight } \\
\text { focus group discussions (FGDs) }\end{array}$ \\
\hline $\begin{array}{l}\text { Abiodun et al. } \\
\text { (2014) }\end{array}$ & Nigeria & $\begin{array}{l}1,250 \text { university students selected by } 2 \text {-stage random } \\
\text { sampling technique using self-administered } \\
\text { questionnaire. }\end{array}$ & A cross-sectional study, with random sampling technique \\
\hline $\begin{array}{l}\text { Bamise et al. } \\
\text { (2011) }\end{array}$ & Nigeria & $\begin{array}{l}592 \text { secondary school pupils from } 5 \text { local } \\
\text { government areas of Osun State, Nigeria }\end{array}$ & $\begin{array}{l}\text { A self-administered questionnaire was used which composed of } \\
\text { questions on their knowledge and sources of information about } \\
\text { HIV/AIDS. }\end{array}$ \\
\hline $\begin{array}{l}\text { Ebeniron } \\
(2010)\end{array}$ & Nigeria & $\begin{array}{l}324 \text { undergraduate students between the ages of } 20 \\
-24 \text { from three tertiary institutions in Rivers State, } \\
\text { Nigeria }\end{array}$ & $\begin{array}{l}\text { A survey questionnaire was administered to a purposive selected } \\
\text { sample from a few Faculties in each Tertiary Institution. }\end{array}$ \\
\hline Oliha (2014) & Nigeria & $\begin{array}{l}600 \text { undergraduates randomly selected from three } \\
\text { universities in Edo State }\end{array}$ & $\begin{array}{l}\text { A researcher constructed questionnaire was used to test the five } \\
\text { hypotheses formulated for the study }\end{array}$ \\
\hline Jimo (2012) & Nigeria & $\begin{array}{l}300 \text { students ( } 150 \text { male and } 150 \text { females), ages } 13 \text { to } \\
19 \text { years drawn from } 10 \text { secondary schools in Lagos } \\
\text { state of Nigeria }\end{array}$ & Data were obtained using a researcher developed questionnaire. \\
\hline $\begin{array}{l}\text { Arogundade } \\
\text { and Faloore } \\
(2012)\end{array}$ & Nigeria & $\begin{array}{l}\text { The participants in the study were one thousand six } \\
\text { hundred undergraduates }(1600: \mathrm{M}=800 \text { and } \mathrm{F}=800) \\
\text { randomly selected from eight universities in South- } \\
\text { western part of Nigeria, in the age range } 16 \text { to } 30 \\
\text { years old }\end{array}$ & $\begin{array}{l}\text { The AIDS Awareness/ Attitude Scale (AAS) and Dating } \\
\text { Behaviour Questionnaire (DBQ) were used to collect data. }\end{array}$ \\
\hline $\begin{array}{l}\text { Makwe and } \\
\text { Ahmad (2014). }\end{array}$ & Nigeria & $\begin{array}{l}\text { A total of } 356 \text { out of } 405 \text { questionnaires completed } \\
(87.7 \%) \text { were analysed }\end{array}$ & $\begin{array}{l}\text { Stratified random sampling method was used in the administration } \\
\text { of a detailed semi structured questionnaire which identified socio- } \\
\text { demographic characteristics, }\end{array}$ \\
\hline $\begin{array}{l}\text { Oruonye } \\
(2012) .\end{array}$ & Nigeria & $\begin{array}{l}\text { Three hundred and eight (308) questionnaires were } \\
\text { administered in the four institutions. }\end{array}$ & $\begin{array}{l}\text { A survey research design with a choice and open format } \\
\text { questionnaires. }\end{array}$ \\
\hline $\begin{array}{l}\text { Ebong and } \\
\text { Ebong (2013). }\end{array}$ & Nigeria & $\begin{array}{l}500 \text { students, } 260(52 \%) \text { were males while } 240 \\
(48 \%) \text { were females. Inclusion criteria were } \\
\text { apparently healthy adolescent consisting of male and } \\
\text { female aged between } 11-25 \text { years }\end{array}$ & The cross-sectional study was carried with a questionnaire \\
\hline
\end{tabular}

The results collected were extracted from the chosen studies as identified. The findings are stated under result/emerging themes indicating the responses from the participants included in the selected studies. The findings of the study are discussed in Table 2.

Table 2: Results/Emerging Themes of the Studies Selected

\begin{tabular}{|c|c|c|c|}
\hline $\mathbf{S} / \mathbf{N}$ & $\begin{array}{l}\text { ARTICLE } \\
\text { AUTHOR }\end{array}$ & METHODOLOGY & RESULTS/EMERGING THEMES \\
\hline 1 & $\begin{array}{l}\text { Mberu } \\
(2010) .\end{array}$ & Survey & $\begin{array}{l}\text { Perception of risks of HIV: } \\
\text {-Some participants perceived no risk of HIV infection: this group of people accepted to have had } \\
\text { premarital sex; the group belonged to a sexually high risk group; different religions and ethnic origins } \\
\text { were considered, the samples they reflected their ethnic origin; education of the participants were also } \\
\text { considered having significant high level of education; the socioeconomic status were considered, } \\
\text { differentiating the higher wealth category from the lowest health category. }\end{array}$ \\
\hline 2 & $\begin{array}{l}\text { Eno et al. } \\
(2013)\end{array}$ & Qualitative & $\begin{array}{l}\text { Mode of transmission: } \\
\text {-Participants demonstrated high level of knowledge about HIV virus. } \\
\text {-Participants were able to enumerate the cause as well a modes of transmission. The participants from the } \\
\text { higher institution were more knowledgeable about the transmission mode compared to others. For } \\
\text { example; } \\
\text { - Female student in the Polytechnic stated that "It is a slow killer that can be gotten through } \\
\text { sharp objects e.g. needle". } \\
\text { Male participant in the University added that "HIV is caused by an RNA virus; it is present in } \\
\text { body fluid like blood, semen, vaginal secretion. It could also be contracted through } \\
\text { unsterilized objects, unprotected sexual intercourse". } \\
\text { Another male participant in the University itemised that 'To state but a few, HIV and AIDS } \\
\text { transmission can be from mother to child, from individual to individual and from object to } \\
\text { individual". } \\
\text { However, some other group that dropped out of school had a different view about HIV, having little or } \\
\text { no knowledge about the transmission of the virus. For example; } \\
\text { - A female out of school youth stated that "it was first transmitted through dog by white people" } \\
\text { "is a disease in the body where positive and negative blood comes together' and can be } \\
\text { transmitted through "Kissing and sharing of cup". Some members of the group were of the } \\
\text { opinion that "it is a disease that kills fast". Others mentioned the use of sharp objects and } \\
\text { "having more than one boyfriend" "going to party", "truancy in school" as a mode of } \\
\text { transmission. }\end{array}$ \\
\hline
\end{tabular}




\begin{tabular}{|c|c|c|c|}
\hline & & & $\begin{array}{l}\text { Knowledge of ways of Preventing HIV/STI: } \\
\text {-Generally, participants were more about "avoidance of practice of sharing sharp objects was the way of } \\
\text { staying HIV free" } \\
-\quad \text { - "uther means of preventing HIV were stated to be } \\
\text { - "using sterilized object all the time" } \\
\text { - "testing of blood before transfusion" } \\
\text { - "knowing the (HIV) status of your partner" } \\
\text { A female tertiary institution student added the following; } \\
\text { "as a lady have your own set of manicure instruments" } \\
\text { Followed by another male tertiary institution student who stated that } \\
\text { "use of protective methods like condom or } \\
\text { total abstinence from sex" } \\
\text {....Would be the best ways to protect and prevent from HIV virus. } \\
\text { Attitude of respondents toward People Living with HIV and condom use: } \\
\text {-many participants had empathy towards HIV infected people indicating that they face social, } \\
\text { psychological and economic related problems } \\
\text {-On the contrary, other participants appeared to stigmatizing people living with HIV. According to the } \\
\text { participants; } \\
\text {..."some HIV people are wicked and will purposely cut their hands and put their blood in their food for } \\
\text { people to eat" } \\
\text { (Female out of School participant) } \\
\text { ".."people with HIV in this environment cannot disclose their status because they don't want others to } \\
\text { talk about them" (FOSY participant) } \\
\text { (A male participant) }\end{array}$ \\
\hline 3 & $\begin{array}{l}\text { Oladepo and } \\
\text { Fayemi } \\
(2011)\end{array}$ & Survey & 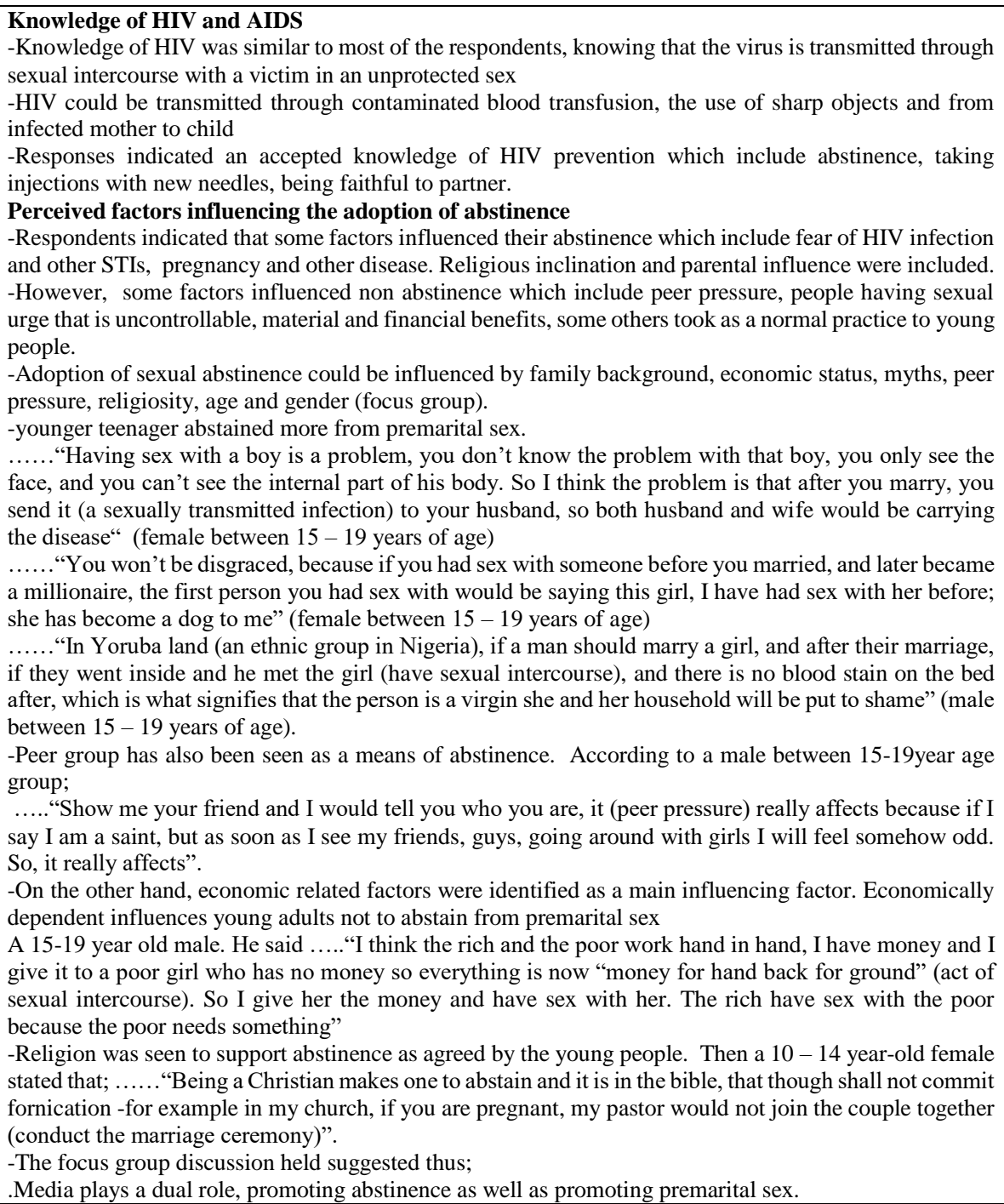 \\
\hline
\end{tabular}




\begin{tabular}{|c|c|c|c|}
\hline & & & $\begin{array}{l}\text {-Increased HIV awareness, made possible from the mass media and healthcare workers. Family and } \\
\text { friends were also other sources of awareness. Participants identified having an unprotected sex with } \\
\text { someone that has been infected, mother to child transmission and blood transmission. } \\
\text { Participants showed high knowledge of preventive measures to be faithfulness to a partner that is not } \\
\text { infected, abstinence, using condoms consistently. However, there was a very low knowledge of } \\
\text { HIV/AIDS treatment. Participants could only state that HIV has no cure } \\
\text { The knowledge of method of HIV prevention was quite high. The participants correctly identified } \\
\text { abstinence as a more effective way of preventing HIV among unmarried young people. }\end{array}$ \\
\hline 5 & $\begin{array}{l}\text { Bamise } \text { et al. } \\
\text { (2011) }\end{array}$ & $\begin{array}{l}\text { self-administered } \\
\text { questionnaire }\end{array}$ & $\begin{array}{l}\text { Knowledge and awareness of HIV } \\
\text {-More young people showed low level of knowledge of HIV virus in terms of transmission. However, } \\
\text { some young people stated that the virus be transmitted by sleeping in the same room with an infected } \\
\text { person, some stated it could be transmitted when sharing bathrooms, by holding hands, touching or } \\
\text { hugging, sitting next to a victim and sharing meal with the victim, kissing the victim and through mosquito } \\
\text { bites. } \\
\text {-Few others showed better level of HIV transmission knowledge stating that virus can be transmitted } \\
\text { through unsterile instruments, blood transfusion, from mother to an unborn child. } \\
\text { Prevention of HIV infection } \\
\text {-Most of the young people believed that protective measures such as use of condoms can prevent HIV, } \\
\text { avoiding sexual intercourse. }\end{array}$ \\
\hline 6 & $\begin{array}{l}\text { Ebeniron } \\
\text { (2010) }\end{array}$ & Survey & $\begin{array}{l}\text { Believe about HIV infection } \\
\text { - Young people are economically exposed to HIV } \\
\text {-Physically exposed to HIV through violence and coerced sex, intimate partner abuse, and rape. } \\
\text {-Women facing more physical abuse than men } \\
\text {-Females being more risky to HIV than men as they cannot protect themselves from most rape and violent } \\
\text { sex. } \\
\text {-Young people have social exposure that encourages HIV spread such polygyny practices. } \\
\text {-young people from s University in Nigeria accepted to have more than one sexual partner, engaging in } \\
\text { an unprotected sex even with the knowledge of HIV. } \\
\text { Knowledge and awareness of HIV infection } \\
\text { - Young people believed HIV can be transmitted through kissing, hugging, handshakes. } \\
\text {-Some others actually had a better knowledge of HIV transmission which could be through sexual } \\
\text { intercourse, sharing unsterilized equipment, injections as well as transfusion of contaminated blood. } \\
\text { Behavioural risk to HIV infection } \\
\text {-Young people engage in high risks sexual behaviour of not using condoms even with the knowledge of } \\
\text { HIV infection and transmission modes. } \\
\text {-Females having less power to bargain and convince their partners to using condoms. } \\
\text {-Young people having multiple sexual partners }\end{array}$ \\
\hline 7 & Oliha (2014) & & $\begin{array}{l}\text { Knowledge and awareness of HIV } \\
\text {-Both young female and male were aware of HIV virus due to educative messages, peer educator } \\
\text { programmes, seminars and workshops on campus at the university } \\
\text { Perception and HIV infection } \\
\text {-many of the young people thinks they have very low or no chance of getting infected. That is, they are } \\
\text { not in any risk. }\end{array}$ \\
\hline 8 & Jimo (2012) & Questionnaire & $\begin{array}{l}\text { Perceptions and HIV } \\
\text {-Pronouncing HIV as a non-existing disease condition. It's a problem as these are students in the } \\
\text { University that are supposed to be informed. } \\
\text { - Young people in the university claimed not to have seen Nigerians with HIV and said HIV only afflicts } \\
\text { the white, and they have not seen any black person with the virus. } \\
\text {-young people saw HIV as a part of political development only and not a disease that is really in existence } \\
\text {-they felt it affects only the white people and homosexuals } \\
\text {-they concluded it was a conspiracy from the western world to spread the news about HIV virus to limit } \\
\text { Africans population growth } \\
\text {-The young people said those that was said they died of HIV was only affliction from witchcrafts in their } \\
\text { families in which treatment are sort from various means rather than medical } \\
\text {-Knowledge and awareness of HIV } \\
\text {-Most young people showed very low knowledge of HIV compared to few of their counterparts } \\
\text {-However, most of the young people did not know that condoms can protect them from HIV. }\end{array}$ \\
\hline 9 & $\begin{array}{l}\text { Arogundade } \\
\text { and Faloore } \\
\text { (2012) }\end{array}$ & & $\begin{array}{l}\text { Awareness and attitude to HIV/AIDS } \\
\text {-most young people had high knowledge of HIV. } \\
\text {-sexual risk behaviour of those young people that have good knowledge of HIV was found to be better } \\
\text { than those that had low knowledge about the virus } \\
\text { - Young people that had good knowledge of HIV applied measures to prevent the condition unlike their } \\
\text { counterparts that could not apply any protective measure because they had little or no knowledge of } \\
\text { HIV/AIDS. }\end{array}$ \\
\hline 10 & $\begin{array}{ll}\text { Makwe and } \\
\text { Ahmad } \\
\text { (2014). }\end{array}$ & & $\begin{array}{l}\text { Knowledge and awareness of HIV } \\
\text {-Majority of the young people in the sample showed high level of knowledge about HIV virus. } \\
\text {-very few among the students agreed to be using condoms regardless of their high level of HIV } \\
\text { knowledge. } \\
\text {-Majority initiated sex as early as when they were } 15 \text { years of age. }\end{array}$ \\
\hline 11 & $\begin{array}{l}\text { Oruonye } \\
\text { (2012). }\end{array}$ & Survey & $\begin{array}{l}\text { Awareness and knowledge of HIV/AIDS } \\
\text { - Young people were able to list out the different modes of transmission } \\
\text {-they were able to list some signs and symptoms of the disease } \\
\text {-they knew that HIV could result into death } \\
\text { Prevention of HIV transmission }\end{array}$ \\
\hline
\end{tabular}




\begin{tabular}{|c|c|c|}
\hline & & $\begin{array}{l}\text { - They believed abstinence from sex could prevent transmission } \\
\text {-Safe sex with the use of condom was believed to prevent HIV transmission } \\
\text {-Single sex partner was believed to prevent HIV transmission } \\
\text {-Proper educative measure could help prevent HIV infection as it could inform people and change their } \\
\text { sexual behaviours }\end{array}$ \\
\hline 12 & $\begin{array}{ll}\text { Ebong } & \text { and } \\
\text { Ebong } & \\
\text { (2013). } & \end{array}$ & $\begin{array}{l}\text { Knowledge and awareness of HIV } \\
\text {-Majority of the young adults were aware of the virus and agreed to join the abstinence group } \\
\text {-Majority showed great awareness of HIV, its causes and transmission. } \\
\text {-very few showed low awareness of the virus } \\
\text { HIV and its prevention } \\
\text {-Young people were aware of the preventive measures to HIV transmission } \\
\text {-Many young people attending counselling and seminars to gain more knowledge of the disease }\end{array}$ \\
\hline
\end{tabular}

Generally, it is said that the youthful population is the hope of the future, which indicates the role of the youth in society and how they can positive or negatively affect development (Diala et al., 2011; Eno et al., 2013). According to Diala et al. (2011), youths are the future of tomorrow, therefore, "a vital quality of the youth population is the fact that they constitute the next generation of parents, workforce and leaders of the society" (Eno et al al., 2013:1106). Significantly, the extent of future societal adaptation depends on the present generation of young people (Okonofua, 2013). As a result, their health foretells so much about them and future generations (Ragsdale-Hearns, 2012). Therefore, the knowledge and awareness of HIV is very crucial to conceal the existing gaps noticed in young people regarding their knowledge awareness of HIV, and HIV transmission (Okonofua, 2013).

However, in the presence of lack of knowledge among some young people in Nigeria, a number of them have however shown good knowledge and awareness of HIV, it transmission and prevention according to the review papers. In the study of Oruonye (2013), the level of awareness and knowledge of HIV among young people was acceptable as they were able to list out the different modes of transmission, made mention of the signs and symptoms of the condition, and even stated that disease could result into death. Accordingly, Oladepo and Fayemi (2011), in their study, young people communicated effectively concerning HIV/AIDS, and demonstrated a high level of knowledge and awareness of the condition. This group of young people added that HIV can be transmitted through contaminated blood transfusion, the use of sharp objects and from mother to child. They further identified that the virus can be transmitted through sexual intercourse and unprotected sex with an infected person (Oladepo and Fayemi, 2011).

Furthermore, more recent research among the selected papers have equally identified a high level of knowledge and awareness among young people (Abiodun et al., 2014; Oliha, 2014). In the study of Abiodun et al. (2014), a cross-sectional study revealed a very high extent of HIV awareness among young people in Nigeria. In their study, young people indicated high knowledge on how HIV can be prevented which included using condoms during sexual intercourse, faithfulness, total abstinence. Participants were able to state that HIV had no cure. Their cross-sectional study established the high knowledge of the young people was basically from the healthcare workers, mass media, family and friends.

Regardless of the extent of knowledge found in few studies, Arogundade and Faloore (2012) argued that the knowledge they have acquired has not impacted their lifestyles. Federal Ministry of Health (2008) and Abiodun et al. (2014) argued that a universal awareness in Nigeria is yet to be achieved. Hence, the lifestyle of young people is not stable as many other youths are lacking the necessary awareness. Therefore, peer pressure is one of the factors that influence most young people in engaging in transactional sex which could also lead to prostitution (Abiodun et al., 2014). Significantly, knowledge influences behaviour and lifestyle (Federal Ministry of Health, 2008, Ragsdale-Hearns, 2012). However, it has evidently been established that knowledge and awareness is not a predictor for a change of behaviour, however, could apparently be a prerequisite to influence behaviour (RagsdaleHearns, 2012).

Consequently, results from reviewing the review papers such as Bamise et al. (2011), Ebong and Ebong (2013) and Abiodun et al. (2014) have confirmed that some participants in the studies have refused to make use of knowledge that has been provided. Few other studies have also well shown different levels of knowledge in their participant; some having very low knowledge and awareness while the others have good knowledge awareness, creating a gap between the same in a group (Bamise et al., 2011; Arogundade and Faloore, 2012; Jimo, 2012; Ebong and Ebong 2013). Arogundade and Faloore (2012) established in their study that several factors could lead to lack of knowledge; which could not only be not assimilating of thought concepts but also putting what has been thought into practice or total lack of exposure. Generally, good knowledge and awareness of HIV have been associated with the sustained programme in health education in Nigeria (Jimo, 2012). Conversely, lack of exposure or health education increases the lack of knowledge and awareness which also have a great impact in the spread of HIV virus. Hence, there is a need to make health education a priority in the prevention of HIV transmission (Ebong and Ebong 2013)

\subsection{Understanding the Transmission Mode of HIV Virus}

According to Adogu et al. (2014), the understanding of the right modes of transmission of the virus will help reduce sexual promiscuity and activities that can promote the spread of HIV virus. However, in the selected studies, most of the papers identified little as well more understanding of the transmission mode of the virus among their participants. On the same vein, Eno et al. (2013) in their studies, participants did not only demonstrate high level of knowledge but also enumerated the various transmission modes and even describes the virus as a slow killer. In their contribution they said; "It is a slow killer that can be gotten through sharp objects e.g. needle"(Female student in the Polytechnic); that "HIV is caused by an RNA virus; it is present in body fluid like blood, semen, vaginal secretion. It could also be contracted through unsterilized objects, unprotected sexual intercourse" (Male participant in the University); and that "HIV and AIDS transmission can be from mother to child, from individual to individual and from object to individual" (Another male participant in the University). This has shown that having access to information and willingness to utilize it will in turn give good understand and good performance.

Abiodun et al. (2014) also revealed increased participants"' understanding of the various transmission modes of the virus. However, the understanding of the participants in Abiodun et al. (2014) was not as strong as those in Eno et al. (2013). On the other hand, consideration is given to the level of exposure and extent of education and means of education and awareness. Conversely, the participants in Eno et al. (2013) were university student went varied level of health education, even from the media whereas the participants from Abiodun et al. (2013) had their awareness and knowledge from the media, friends and family member. Hence, exposure level has a great effect and has a high capacity to influence on the level of understanding and also influences performance.

Similarly, previous studies on health education programmes have equally proven effectiveness of education in the performance of young people towards preventing HIV transmission (Adogu et al., 2014). United States. Congress. House. Committee on Oversight and Government Reform (2010) conducted a study on Domestic Abstinence-only Programs; their study revealed an increase in the knowledge of the participants. As a result, there was an increased belief in abstinence among young people. Consequently, the programme influence young people to postpone having early or premarital sex, and wait until marriage to prevent or to avoid to risk of getting infected with HIV virus. Hence, Domestic Abstinence-only Programs helped in influencing beliefs, knowledge and intensions on abstinence among young people. The result of this study agrees with Eno et al. (2013), one of the review papers were the respondents indicated abstinence as the best way to prevent HIV virus infection.

Conversely, the same group of people in the same environment or exposure may not only be inconsistent in their responses but also lacks the required understanding to the concept under study such as the mode of HIV transmission. The study of Eno et al. (2013) however, also revealed student that were in the same university as their counterparts giving unacceptable responses, mixing things up. Although they were tagged as "drop outs" which could be associated with not being educational cognizant. The student had 
different views compared to their counterparts; in their responses they stated that; "it was first transmitted through dog by white people" (A female out of school youth dropout), that "is a disease in the body where positive and negative blood comes together' and can be transmitted through 'Kissing and sharing of cup". Some members of the group were of the opinion that "it is a disease that kills fast". Others mentioned the use of sharp objects and "having more than one boyfriend" "going to a party", "truancy in school" as a mode of transmission. Contradiction knowledge was found among the young people. Hence, there is need for a proper enlightenment.

\subsection{Understanding the Preventive Measures}

The awareness and knowledge of HIV virus is closely related to adopting preventive measures to avoid getting infected (Ragsdale-Hearns, 2012) Similarly, in Ebong and Ebong (2013), many participants gained more knowledge in attending seminars and counselling and become highly knowledgeable and aware of the preventive measures of HIV virus. However, few other participants did not show any improvement in their knowledge and awareness. Oruonye (2012) also supported the view of educating improving knowledge and awareness. In Orunye's study, it was revealed that prope educative measure could help prevent HIV infection as it could inform people and change their sexual behaviours, influencing them to engage in single sex partner, safe sex as preventive measures of HIV transmission and believed abstinence could prevent HIV transmission.

Similarly, the study of Bamise et al. (2011) revealed that Most of the young people believed that protective measures such as use of condoms can prevent HIV, avoiding sexual intercourse. Conversely, this shows high level of awareness and understanding of how HIV could be prevented. Although Ragsdale-Hearns (2012) established that preventive measures are country specific as there are different factors to consider that affects individuals in different geographical locations. Thus, the participants have stressed on the use of condoms, above all, avoiding sexual intercourse. In the study of Abiodun et al. (2014) and Eno et al. (2013), participants equally demonstrated very high level of understanding of how HIV could be prevented. The study of Eno et al. (2013) went further to mention testing blood transfusion before actually transfusing, using sterilized objects at all times, insisting on knowing the status of a partner before engaging a sexual relationship.

According to Ragsdale-Hearns (2012), the virus can only prevented if there is increased awareness and knowledge about the causes and transmission modes. Hence, there is a close relationship between the awareness and understanding the preventive measures. Okonofua, 2013 argued that preventive measures strategies should be a youth-focused prevention providing accurate and factual information which Karim and Karim have considered as a primary goal for programmes designated for intervention to be able to conquer the myth associated with the transmission of the virus. Additionally, intervention information should be able to promote and informed choice and youths should always be encouraged to participate in such programmes to enhance prevention.

\subsection{Risk Perceptions and Misconceptions of HIV Infection}

Young people perceive HIV infection in different ways; this can be affected by educational level or exposure to HIV related issues (Jimo, 2012). Studies have revealed the different perceptions of young people towards HIV infection. In the study of Mberu (2010), it was revealed that some participant perceived no risk of HIV infection: this group of people accepted to have had premarital sex; the group belonged to a sexually high-risk group; differen religions and ethnic origins were considered, the samples they reflected their ethnic origin; education of the participants was also considered having significant high level of education; the socioeconomic status was considered, differentiating the higher wealth category from the lowest health category.

According to Mberu (2010) it is common that youth with some level of education are not relative to those with no education. Same for religion and ethnic group values. Essential, education is a ground for learning and those around it gain so much from different kinds of studies where seminars, workshops and classes are conducted to discuss HIV, its causes, transmission mode and prevention. Hence, they have a better exposure compared to those that are not in such an environment. Conversely, Mberu outlined that a highly significant level of education had influenced young people in college to have a good approach to HIV prevention than those that not in college. Same as for religious views, as some religions frown against premarital sex. Hence, their members tend to engage in total abstinence. Likewise, ethnic values where parents encourage and influence their children from abstaining from sex unti marriage.
However, young people have been noticed to be closely associated with having determination in their activities, engaging in I different activities that could be risky to them and others (Wangulu, 2008). Wenzel et al. (2012) argued that young people are vulnerable group of people due to involvement in risky practices regardless of how they perceive it. Mberu (2010) recorded in his study that young people chances of being infected with HIV is perceived to be low among them. Correspondingly, some young students from the university perceived that they are not likely to contact HIV infection. Some other group of young people however believed that they were not by any means going to be infected (Oliha, 2014).

Consequently, as a result of how low young people have perceived the risk of getting infected with HIV virus. Thus, they are careless about taking preventive measures and engage in casual sex. Most engaged in premarital sex without adopting any preventive measures (Andersen et al., 2015). Significantly, according to Bakhoum et al. (2014), sexual practices of most young people were based more on what they believed due to lack of knowledge or awareness about the reality of HIV virus. As a result, there are misconceptions about HIV infection and spread among young people. Jimo (2012) revealed the misconception of young people had series of misconceptions about HIV.

The study of Jimo (2012) revealed that young people had misconceptions and beliefs concerning HIV. Jimo reported that young people had the believe that HIV is a non-existing disease. However, it was a concern as the participants were university students who are supposedly have the required preventive information about the condition. Jimo went further to state that young people even claimed not to have seen a Nigerian with HIV. Hence, they concluded HIV only afflicts the white people because they have not seen any black person with HIV. The same group of student also assumed that HIV is a part of political development and not a disease that really exists. Few others stated that it affects more of homosexuals among white people. However, they concluded it was a conspiracy from the western world to spread the news about HIV virus to limit Africans population growth.

Furthermore Eno et al. (2010) reported that young people believed that HIV is when negative and negative blood comes together. Disappointingly, some stated that HIV can be contracted through sharing of cup and kissing, some others mentioned going to party to truancy in school as a mode of transmission of HIV. Equally, Bamise et al. (2011) publicised that young people stated that the virus be transmitted by sleeping in the same room with an infected person, by holding hands, touching or hugging an infected person. Significantly, reports have equally shown that concerns of contracting HIV is minimal among young adults (Gross, 2013). However, some young people are actually prone to it due to certain misconceptions and beliefs they have (Arogundade and Faloore, 2012). As a result, the study of Makwe and Ahmad (2014) revealed that majority of young people initiated sex as early as when they were 15 years of age, hence putting themself and others who they might have sexual intercourse at a high risk of contracting the disease.

\subsection{Factors Influencing Sexual Behaviour}

Oladepo and Fayemi (2011) revealed that the knowledge of HIV was similar to most of the respondents, knowing that the virus is transmitted through sexual intercourse with a victim in unprotected sex. However, different factors have been noted to influence sexual behaviour among young people in Nigeria. Similarly in the study of Oladepo and Fayemi (2011) respondents indicated that some factors influenced their abstinence which includes fear of HIV infection and other STIs, pregnancy and other disease. Religious inclination and parental influence were included. However, some other factors influenced non-abstinence which includes peer pressure, people having sexual urge that is uncontrollable, material and financial benefits, some others took as a normal practice to young people.

The change in young people's sexual activities has mostly been attributed to behavioural changes in both sexes but more in males (Ebeniron, 2010). This has been linked to the study of Oladepo and Fayemi (2011) that indicates that women have less power to decide whether a man should use condom during sexual intercourse. However, most of the women are also said to be influenced due to economic reasons where females engage in casual sex to be able to raise money to support themselves, in the case they have less options to dictate how they wanted it but can only go with the decision of the males. On the same vein, Oladepo and Fayemi (2011) revealed that young people actually stated that "I think the rich and the poor work hand in hand, I have money and I give it to a poor girl who has no money so everything is now "money for hand back for ground" (act of sexual intercourse) (A 15-19 year old male). Significantly, economic related factors were identified as a main influencing factor. 
Economic issues influences young adults not to abstain from premarital sex. Similarly, Ebeniron (2010) recorded that Young people are economically exposed to HIV.

On the contrary, most young people have been positively influenced to abstain from premarital sex. According to Oladepo and Fayemi (2011), religion was seen to support abstinence as agreed by the young people. One of the respondents indicated that Being a Christian makes one to abstain and it is in the bible, that thou shall not commit fornication -for example in my church if you are pregnant, my pastor would not join the couple together (conduct the marriage ceremony)". Peer group has also been seen as a means of abstinence according to a male between 15-19year age group in the study of Oladepo and Fayemi (2011). Media was also seen to promote abstinence, however, it plays a dual role, promoting abstinence as well as promoting premarital sex.

\subsection{Attitudes towards Individuals Living with HIV}

HIV/AIDS is taken to be the consequences of one's sins, the victims are faced with some metaphors and are bound to face punishment, horrors, guilt and death. This brings rejection, stigmatization and discrimination among thei peers, family, and in their place of work. However, studies have equally shown different views of young people towards people living with HIV. Surprisingly, many participants had empathy towards HIV infected people indicating that they face social, psychological and economic related problems. On the contrary, other participants appeared not to only be stigmatizing people living with HIV but also stated that some HIV people are wicked and will purposely cut their hands and put their blood in their food for people to eat (Eno et al. 2013).

However, Okonofua (2014) argued that HIV victims are faced with differen levels of traumatic states, leaving them with huge emotional stress. Hence, the study of Eno et al. (2013) revealed that most people with HIV in this environment cannot disclose their status because they don't want others to talk about them. It was also stated that stigma could push them to intentionally distribute the virus. However, the results prove that HIV patients are retaliating to the trauma they are facing from stigmatisation, discrimination and rejection from the society, especially from those that are relatively close to them.

\section{Conclusion and Recommendation}

Lack of knowledge and understanding has been identified as a potential risk factor affecting the way they reason and behave. Knowledge of HIV/AIDS does not only influence the way young adults behave but also help them to adopt some prevention methods, rather than engaging in casual sex, in turn preventing HIV and other STIs. Some young adults has also been identified to have little knowledge, having vague ideas on HIV virus and its prevention, in the same vein, poor knowledge of HIV and its prevention can equally predispose young people to being vulnerable to HIV as they have limited knowledge on how it will be prevented as well as modes of transmission.

Furthermore, Young people also exhibited different levels of risk perceptions which could be from different reasons including the exposure and level of understanding, some perceived no risk of contracting HIV, some perceived low while some high risk. However, their perceived level of risk affected their behaviours and engagements. Nevertheless, there were other factors that influenced their sexual behaviours which includes socioeconomic status; level of individual need. Poverty; increase need for sex and peer pressure Significantly, factors such as socioeconomic factors, religion, ethnic values, parental influence, and media were found to influence young people's behaviour towards sex.

Significantly, the study undertook confirms the original theme of the dissertation regarding the vulnerability of younger people of low socioeconomic background with regards to contracting HIV in Nigeria. The themes confirm the problem statement of the study to address the aim of the study. However, addressing the aim of the study in terms of young people's perceptions, attitudes and behaviour towards the risk of HIV, it has been revealed that socioeconomic status, lack of knowledge, risk perceptions can influence young people's attitudes and behaviours with a high risk of contracting HIV infection. Therefore, the following recommendations are made to enhance more stringent policy and its implementation to curb the spread of HIV infection. Based on the findings of the study, the following recommendations were made;

Continual and more productive health education to every part of living for young people emphasises on the impact of the virus on our population and productivity.
There is an urgent need to ensure the adoption and implementation of schoolbased HIV educational programmes to inculcate and influence the right attitude, behaviours and improved knowledge to enhance the prevention of HIV transmission among young people.

Implementation of improved multi-sectoral approaches to HIV/AIDS education, encouraging greater participation of young people both in the university/college of outside to be able to involved more number of young people.

Curriculums in universities, colleges, and all schools in general should include HIV/AIDS education to enhance its prevention.

Religious leaders, clergy men, lecturers, and parents should device diverse means of enlightening young people on the need for positive behavioural attitudes, academic focus and moral uprightness as they are leaders and parents of tomorrow.

The efforts of HIV/AIDS campaigns should be intensified among nongovernmental organizations, voluntary organizations and the Government to increase awareness level through the media, seminars, lectures, post and handbill. More stringent adoption and implementations of policies on matters that will reduce the spread of HIV virus should be strictly adhered to.

\section{References}

Abiodun, O., Sotunsa, J., Ani, F. and Ebunoluwa Jaiyesimi, E. (2014) Knowledge of HIV/AIDS and predictors of uptake of HIV counseling and testing among undergraduate students of a privately owned university in Nigeria. BMC Research Notes, Vol. 7, Vol. 639, Pp. 1-8.

Adedimeji, A. A., Omololu, F. O., \& Odutolu, O. (2007). HIV risk perception and constraints to protective behaviour among young slum dwellers in Ibadan, Nigeria. Journal of health, population, and nutrition, 25(2), 146-157.

Adogu P, Udigwe I, Nwabueze A, Adinma E, Udigwe G, Onwasigwe C. (2014). Sexual health knowledge, attitude and risk perception among inschool and out-of-school female adolescents in Onitsha, Anambra State, Nigeria. Vol. 1, Pp. 1-12.

Aggleton, p., Moatti, j. p., Prieur, A., Sandfort, T. and Souteyrand, Y. (2000). AIDS in Europe: New challenges for the social sciences. London. Routledge.

Ahmed, S., Lutaloa, T., Wawerb, M.; Serwaddac, D.; Sewankambo, N. K.; Nalugodaa, F.; Makumbia, F.; Wabwire-Mangenc, F.; Kiwanukaa, N.; Kigozia, G.; Kiddugavua, M and Gray, R. (2001). "HIV incidence and sexually transmitted disease prevalence associated with condom use: a population study in Rakai, Uganda”, AIDS, Vol. 15, Iss. 16, Pp. 2171 2179.

Andersen, M., Taylor, H. and Logio, K. (2015). Sociology: The essentials. Stamford. Cengage Learning.

Arogundade, O. T. and Faloore O. O. (2012). Hiv/Aids awareness as a predictor of university students' dating behaviour in South - Western Nigeria. International Journal of Psychology and Behavioral Sciences, Vol. 2, Iss. 1, Pp. 9-14.

Bakhoum, A. Y., Bachmann, M. O, Kharrat, E. I. and Talaat, R. (2014) Assessment of Knowledge, Attitude, and Practice of Risky Sexual Behaviour Leading to HIV and Sexually Transmitted Infections among Egyptian Substance Abusers: A Cross-Sectional Study. Hindawi Publishing Corporation Advances in Public Health. Vol. 8, Pp. 1-9.

Bamise, O. F., Bamise, C. T. and Adedigba, M. A. (2011). Knowledge of HIV/AIDS among secondary school adolescents in Osun state, Nigeria. Nigerian Journal of Clinical Practice, Vol. 14, Iss. 3, Pp. 338-344.

Barone, D. F., Maddux, J. E. and Snyder, C. R. (2012). Social Cognitive Psychology: History and Current Domains. London. Springer.

Bernardi, L. (2002) Determinants of individual AIDS risk perception: knowledge, behavioural control and social influence, African Journal of AIDS Research, 1:2, 111-124, DOI: 10.2989/16085906.2002.9626551.

Bettany-Saltikov, J. (2012). How to do a systematic literature review in nursing: A Step-By-Step Guide. Berkshire. Open University Press.

Biggs, N. A. (2012). Education and HIV. New York. Continuum International Publishing.

Biraro, S., Shafer, L. A., Kleinschmidt, I., Wolff, B., Karabalinde, A., Nalwoga, A., Musinguzi, J., Kirungi, W., Opio, A.Whitworth, J. and Grosskurth, H. (2009). "Is sexual risk taking behaviour changing in rural south-west Uganda? Behaviour trends in a rural population cohort 1993 2006", Sexually Transmitted Infections, Vol. 85, Pp. 3-11.

Booth, A. B., Papaioannou, D. and Sutton, A. (2012). Systematic approaches to a successful literature review. London. Sage. 
Boudreaux, E. D., Cydulka, R., Bock, B., Borrelli, B. andSteven L. Bernstein, S. L. (2009). Conceptual Models of Health Behaviour: Research in the emergency care settings. Academic Emergency Medicine, Vol. 16, Pp. 1120-1123.

Braun, V. and Clarke, V. (2013). Successful Qualitative Research: A Practical Guide for Beginners. London. Sage Publication Limited.

Bulled, N. (2015). Prescribing HIV prevention: Bringing culture into global health communication. California. Left Coast Press.

Caraël, M. and Glynn, J. (2008). HIV, Resurgent Infections and Population Change in Africa. London. Springer.

Christianson, M., Berglin, B. and Johansson, E.E. (2008). It should be an ordinary thing - a qualitative study about young people's experiences of taking the HIV-test and receiving the test result. Caring Sciences, Vol. 10, Pp.1471-6712.

Collins, H. (2010). Creative Research: The theory and practice of research for the creative research. London. AVA Publishing.

Conner, M. (2010). Cognitive determinants of health behaviour. Behavioural Medicine, Vol. 1, Pp. 19-30.

De Walque, D. (2009). Comparing Condom Use with Different Types of Partners: Evidence from National HIV Surveys in Africa, Policy Research Working Paper 5130, The World Bank Development Research Group, November 2009. http://elibrary.worldbank.org/doi/pdf/10.1596/1813-9450-5130 (Accessed 13:02:2015)

Ebeniro, C. D. (2010). Knowledge and beliefs about hiv/aids among male and female students of Nigerian universities. Journal of Comparative Journal of Comparative Research in Anthropology and Sociology, Vol. 1, Iss. 1, Pp. 121-131

Ebewo, P., Stevens, I. and Sirayi, M. (2013). Africa and Beyond: Arts and Sustainable Development. Newcastle Upon Tyne. Cambridge Scholars Publishing.

Ebong, E. and Ebong, I. U. (2013). Adolescents understanding of the concept of HIV and AIDS in Calabar South, South South Nigeria. European Scientific Journal September, Vol. 9, Iss. 27, Pp. 138-146.

Federal Ministry of Health (2008): National HIV/AIDS and reproductive health survey, 2007 (NARHS Plus). Abuja Nigeria: Federal Ministry of Health.

Ferrell, B., Coyle, N. and Paice, J. A. (2015). Oxford textbook of palliative nursing. Oxford. Oxford University Press.

Forrester, M. A. (2013). The development of young children's socialcognitive skills. New York. Psychology Press.

Fox, A. M. (2010). The social determinants of HIV serostatus in sub-Saharan Africa: an inverse relationship between poverty and HIV? Public Health, Vol. 125, Iss. 4, Pp. 16-24.

Fox, A. M. (2012). The HIV poverty thesis re-examined: Poverty, wealth or inequality as a social determinant of HIV in sub-Saharan Africa? Journal of Biosocial Science, Vol. 44, Pp. 459-480.

Gallant, E. (2012). 100 Questions and answers about HIV and AIDS Burlington. Jones and Bartlett Learning.

Gross, M., Goldsmith, A. Y. and Carruth, D. (2013). HIV/AIDS in Young Adult Novels: An Annotated Bibliography. Maryland. Scarecrow Press.

Hair, J. F., Celsi, M. W., Money, A. H., Samouel, P. and Page, M. J. (2011). Essentials of business research methods. 2nd Edition. New York. M. E. Sharp, Inc.

Hajizadeh, M., Sia, D., Heymann, S. J. and Nandi, A. (2014). Socioeconomic inequalities in HIV/AIDS prevalence in sub-Saharan African countries: evidence from the Demographic Health Surveys. International Journal for Equity in Health, Vol. 13, Iss. 18, Pp. 1-22.

Holloway, I. and Wheeler, S. (2013). Qualitative Research in Nursing and Healthcare. 3rd Edition. London. Wiley-Blackwell.

Horton, R. (2008). Putting prevention at the forefront of HIV/AIDS. Lancet, Vol. 372, Pp. 421-422.

Jesson, J., Matheson, L. and Lacey, F. M. (2011). Doing your literature review: traditional and systematic techniques. London. Sage.

Jimo, M. (2012). "I'm Too Young to Catch the Bug": Nigerian adolescent students' perceptions of HIV/AIDS and its influence on their sexual behaviour. Journal of Education and Practice, Vol. 3, Iss. 16, Pp. 166172.

Jones, T. and Mitchell, A. (2014). Young people and HIV prevention in Australian schools. AIDS Education and Prevention, Vol. 26, Iss. 3, Pp. 224-233.

Juma, M. and Klot, J. (2011). HIV/AIDS, gender, human security, and violence in Southern Africa. Africa Institute of South Africa.

Karim, S. S. A. and Karim, Q. (2010). HIV/AIDS in South Africa. $2^{\text {nd }}$ Edition. Cambridge. Cambridge University Press.
Kartikeyan, S., Bharmal, R. N., Tiwari, R. P. and Bisen, P. S. (2015). HIV and AIDS: Basic elements and priorities. Dordrecht. Springer.

Love, K. (2012). Ethics in social research. Bingley. Emerald Group Publishing Limited.

Lowndes, C.M., Alarly, M.; Belleau, M.; Bosu, W.K.; Kintin, D.F.; Nnorom, J.A.; Seck, K.; Victor-Ahuchogu, J. and Wilson, D. (2008). Western Africa HIV/AIDS epidemiology and response synthesis: Characterization of the HIV epidemic and response in West Africa: implications for prevention. Washington, DC, World Bank.

Maddux, J. E. and Tangney, J. P. (2010). Social psychological foundations of clinical psychology. New York. The Guilford Press.

Madkour, A. S., Farhat, T., Halpern, C. T., Godeau, E. and Gabhainn, S. N. (2010). Early adolescent sexual initiation as a problem behaviour: a comparative study of five nations," Journal of Adolescent Health, vol. 47, Iss. 4, Pp. 389-398.

Magezi, V. (2007). HIV/AIDS, Poverty and Pastoral Care and Counselling. Stellenbosch. SUN PReSS.

Makwe, E. and Ahmad, H. A. (2014). Attitude, sexual behaviour and risk perception to sexually transmitted infections including HIV/AIDS among students of university of Abuja, Nigeria. British Journal of Education, Society and Behavioural Science, Vol. 4, Iss. 3, Pp. 350-361

Matzo, M. and Sherman, D. W. (2015). Palliative care nursing: Quality care to the end of life. New York. Springer.

Mayer, K. H. and Pizer, H. F. (2009). HIV Prevention: A comprehensive approach. London. Elsevier.

Mohtasham, G., Shamsaddin, N., Bazargan, M., Anosheravan, K., Elaheh, M. and Fazlolah, G. (2009). Correlates of the intention to remain sexually inactive among male adolescents in an Islamic country: case of the Republic of Iran. Journal of School Health, Vol. 79, Iss. 3, Pp. 123 129

Mooi, E. A. and Garstedt, M. (2011). A concise guide to market reseat: the process, data, and methods of using IBM SPSS statistics. London. Springer.

Mueller, T. E., Gavin, L. E. and Kulkarni, A. (2008). The association between sex education and youth's engagement in sexual intercourse, age at first intercourse, and birth control use at first sexual intercourse. Journal of Adolescent Health, vol. 42, Iss. 1, Pp. 89-96.

Nelson, K. E. and Williams, C. M. (2014). Infectious disease epidemiology: Theory and practice. 3rd Edition. Burlington. Jones and Bartlett Learning.

Obadare, E. (2013). The handbook of civil society in Africa. Kansas. Springer.

Ogunmola, O. J., Oladosu, Y. O. and Olamoyegun, M. A. (2014) Relationship between socioeconomic status and HIV infection in rural tertiary health centre. HIV/AIDS - Research and palliative Care, Vol. 6 , Pp. 61-67.

Okonofua, F. (2013). African journal of reproductive health. Florida. BrownWalker Press.

Oladepo, O. and Fayemi, M. M. (2011). Perceptions about sexual abstinence and knowledge of HIV/AIDS prevention among in-school adolescents in a western Nigerian city. BMC Public Health, Vol. 11, Iss. 304, Pp. 4-10.

Oliha, J. (2014). Investigating study of the knowledge, attitude and opinion of university undergraduates to HIV/AIDS and its screening. International Journal of Asian Social Science, Vol. 4, Iss. 1, Pp. 51-58

Oppenheimer, M. E. (2008). The effects of gender, ethnicity and socioeconomic status on coping with HIV. London. Springer.

Oruonye, E. D. (2012). An assessment of the level of HIV/AIDS awareness and vulnerability in tertiary intstitutions in Jalingo LGA, Taraba State, Nigeria. International Journal of Science and Nature, Vol. 3, Iss. 4, Pp. 805-809.

Ragsdale-Hearns, B. L. (2012). A study of the lack of HIV/AIDS awarenes among African American women: A leadership perceptive. New York. Trafford Publishing

Rapport, F. (2013). New qualitative methodologies in health and social care research. London. Routledge.

Riley, G. R. and Baah-Odoom, D. (2010). Do stigma, blame and stereotyping contribute to unsafe sexual behaviour? A test of claims about the spread of HIV/AIDS arising from social representation theory and the AIDS risk reduction model. Social Science and Medicine, Vol. 71, Pp. 600607.

Sanderson, C. A. (2010). Social Psychology. London. John Wiley and Sons.

Saunders, M., Lewis, P. and Thornhill, A. (2009). Research Methods for Business Students. 5th Edition. Essex. Pearson Education Limited.

Schiering, M. S., Bogner, D. and Jorun Buli-Holmberg, J. (2011). Teaching and Learning: A Model for Academic and Social Cognition. Plymouth Rowman and Littlefield Education. 
Sherr, L. (2013). AIDS and adolescents. Amsterdam. Harwood Academic Publishers.

Shiferaw, Y., Alemu, A., Girma, A. (2011). “Assessment of knowledge, attitude and risk behaviors towards HIV/AIDS and other sexual transmitted infection among preparatory students of Gondar town, north west Ethiopia," BMC Research Notes, vol. 4, Iss. 505, Pp. 1-6.

Silverman, D. (2010). Doing qualitative research. 3rd Edition. London. Sage Publications Limited.

Stolley, K. S. and Glass, J. E. (2009). HIV/AIDS. California. Greenwood Publishing Group.

Tarimo, E. A. M., Francis, J. M., Kakoko, D., Munseri, P., Bakari, M. and Sandstrom, E. (2012). The perceptions on male circumcision as a preventive measure against HIV infection and considerations in scaling up of the services: a qualitative study among police officers in Dar es Salaam, Tanzania. BMC Public Health, Vol. 12, Iss. 529, Pp. 1-12.

Tenkorang, E. Y. and Rajulton, F. (2009). A multi-level analysis of AIDS risk perception, poverty and sexual risk-taking among young people in Cape Town, South Africa. Lecture Note, University of Western Ontario, Canada.

Tracy, S. J. (2013). Qualitative research methods: collecting evidence, crafting analysis, communicating impact. West Sussex. WileyBlackwell.

UK Statistics (2013). People living with HIV in the UK. http://www.nat.org.uk/HIV-Facts/Statistics/Latest-UK-statistics/Peoplewith-HIV-in-UK.aspx (Accessed 03-11-2014).

UNESCO (2013). Measuring the education sector response to HIV and AIDS: Guidelines for the construction and use of core indicators. Paris. United Nations Educational, Scientific and Cultural organisation.
United States. Congress. House. Committee on Oversight and Government Reform (2010). Domestic Abstinence-only Programs: Assessing the Evidence : Hearing Before the Committee on Oversight and Government Reform, House of Representatives, One Hundred Tenth Congress, Second Session, April 23, 2008, Volume 4. Pennsylvania. U.S. Government Printing Office.

Upreti, D., Regmi, P. and Simkhada, P. (2009). Young people's knowledge attitude, and behaviour on STI/HIV/AIDS in the context of Nepal: A systematic review. Kathmandu University Medical Journal, Vol. 7, No. 4, Iss. 28, Pp. 383-391.

Valerio, A., Beasley, M. and Bundy, D. A P. (2012). A sourcebook of HIV/AIDS prevention programs: Education sector-wide approach. Washington. The World Bank.

Wahdan, I., Wahdan, A., Gueneidy, M. and Rahman, I. (2013). "Prevalence and determinants of condom utilization among people living with HIV/AIDS in Egypt," Eastern Mediterranean Health Journal, vol. 19, Iss. 12, Pp. 1-8.

Wangulu, E.F. (2008) Sexuality and gender; behaviour change communication for HIV and AIDS among young people. Exchange on HIV/AIDS, Vol. 1, Pp. 1-4.

Wenzel, S. L., Rhoades, H., Tucker, J. S., Golinelli, D., Kennedy, D. P., Zhou, A. and Ewing, B. (2012). HIV risk behaviour and access to service: What predicts HIV testing among heterosexually active homeless men? AIDS Education and Prevention, Vol. 24, Iss. 3, Pp. 270-279.

Wilson, R. and Kolander, C. (2011). Drug abuse prevention. London. Jones and Bartlett Publishers.

Wiseman, A. W. and Glover, A. N. (2012). The Impact of HIV/AIDS on Education Worldwide. Bingley. Emerald Group Publishing Limited.

- Thank you for publishing with us. 